\title{
Palaeoecological investigations of a Holocene peat deposit from Vølvedal, Peary Land, North Greenland
}

\section{Ole Bennike}

In connection with GGU's expedition to the Peary Land region, North Greenland, in 1979 and 1980 , I had the opportunity to carry out some field work on the Quaternary geology of the Vølvedal area, and to collect a peat section $\left(83^{\circ} 02^{\prime} \mathrm{N}, 34^{\circ} 21^{\prime} \mathrm{W}\right.$; fig. 4$)$. Remains of Alona guttata and Calcarius lapponicus, which do not live in Peary Land today were found.

\section{Topography, geology, climate and vegetation}

The topography is alpine. The bedrock of the area consists of tectonised Lower Palaeozoic clastic sediments and mudstones, partly converted to cherts.

The deglaciation of the area occurred at approximately 8000 B.P. (Funder, 1982). The marine limit is about $55 \mathrm{~m}$ above sea level, as marked by a kame delta at the entrance to the Vølvedal valley. Several driftwood pieces have been found in the river bed of the valley, showing that the sea invaded in Holocene time.

The climate is distinctly high-arctic. The presence of among others Calamagrostis purpurascens and Elymus hyperarcticus is evidence of continental conditions, with relatively high summer temperatures. In general, the vegetation is considerably more luxuriant than at Jørgen Brønlund Fjord, from where meteorological data have been published (Fristrup, 1952, 1961; Meltofte, 1976). Here the mean July temperature is $4-6^{\circ} \mathrm{C}$, and temperatures are above zero for 40 to 60 days.

The vegetation of the valley floor is dominated by Salix arctica, Kobresia myosuroides, Dryas integrifolia and less commonly by Carex misandra, Pedicularis hirsuta and Melandrium triflorum.

Some small Carex stans meadows are found. The peat deposit is covered with dry silt without vegetation.

\section{Laboratory work}

The preparation for pollen analysis followed the procedure outlined by Funder (1978). For determination of loss on ignition the samples were dried at $105^{\circ} \mathrm{C}$ before combustion at

Fig. 4. Locality map. 1: Vølvedal, 2: Sølejren, 3; Klaresø.

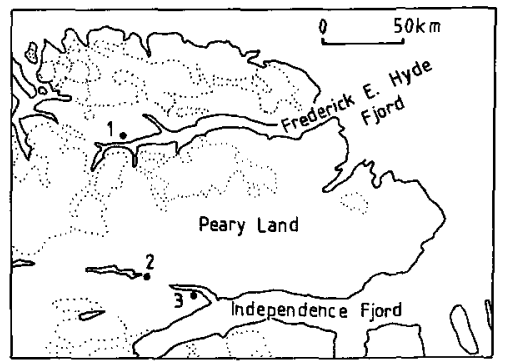


$550^{\circ} \mathrm{C}$. For macrofossil analysis the samples were washed on a $0.4 \mathrm{~mm}$ sieve and sorted in water under a low-power microscope. The mosses have not been determined.

\section{${ }^{14} \mathrm{C}$ date and sedimentation rate}

A single sample $150 \mathrm{~cm}$ below the top of the profile yielded a date of $4850 \pm 95$ B.P. (K-3494; Bennike in Funder, 1982). The dating was carried out on moss fragments only, thereby avoiding contamination by young roots from vascular plants.

Malaurie et al. (1972) recorded a highly varying sedimentation rate for peat from the Thule district, ranging from 0.04 to $1.5 \mathrm{~mm}$ per year, with an average of about $0.4 \mathrm{~mm}$ per year. The amount of peat accumulation in Vølvedal indicates a fast or very fast $(0.08$ to 1.5 $\mathrm{mm}$ per year) sedimentation rate. Nothing more precise can be said on the basis of the single ${ }^{14} \mathrm{C}$ date.

\section{Sediments}

The peat deposit (fig. 5) is underlain by at least $5 \mathrm{~m}$ of silt with about $3 \mathrm{~m}$ of gravel above it. The silt is horizontally laminated without macroscopic body fossils or trace fossils. It is interpreted as having been deposited from suspension in tranquil water, perhaps in connection with the invasion of the sea. The gravel is pebbly and grain-supported showing imbrication. It is interpreted as glaciofluvial, having been deposited after some lowering of the sea had taken place.

The peat has been separated into three units. The lowest, corresponding to biozone 1, consists of silt with 5-10 per cent organic material. This is made up of herb and Salix fragments, whereas moss fragments are rare. The middle unit consists, especially in the upper part, almost exclusively of mosses, predominantly Drepanocladus $\mathrm{cf}$. brevifolius $(=D$. lycopodioides var. brevifolius). The small inorganic fraction is made up of (?) windblown silt and sand. The upper unit shows an increasing content of silt, ending with almost pure silt. This silt is interpreted as a loess deposit.

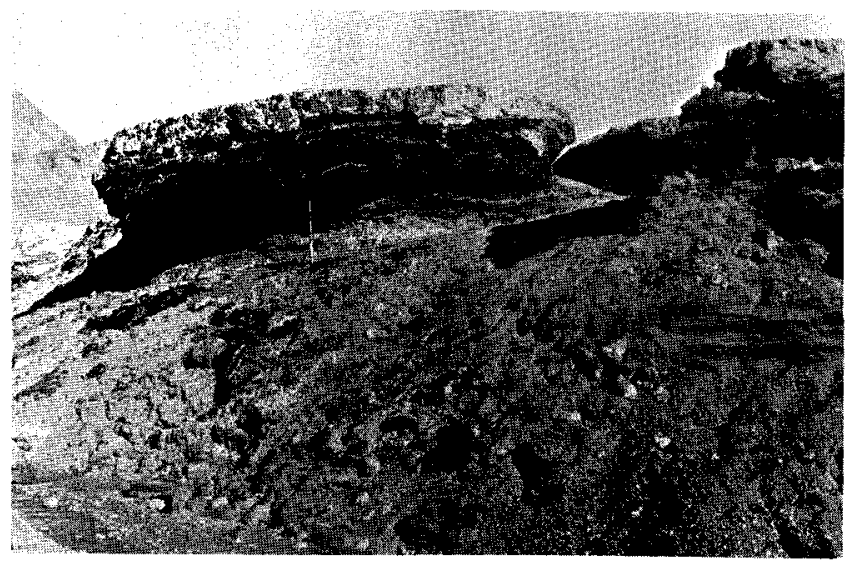

Fig. 5. Part of the peat deposit. The stick measures $120 \mathrm{~cm}$. 


\section{Biozones}

The sequence has been divided into two biozones on the basis of pollen and macrofossils (fig. 6).

Biozone 1: Carex stans - Salix arctica zone. Cyperaceae, Salix and gramineae pollen dominate this zone. Achenes of Carex stans are frequent, whereas achenes of Carex misandra are rare. The gramineae pollen apparently originates from outside the sampling site, as no seeds of this family have been found. Leaves and twigs of Salix arctica are common. The Dryas integrifolia leaves are probably wind-transported, as no twigs of this species were found. A rather diverse assemblage of herb seeds is also present.

Biozone 2: Carex stans zone. Cyperaceae pollen make up 70 to more than 90 per cent of the total pollen. According to the macrofossil content Carex stans is by far the most abundant species. Sample no. 7 shows a deviating macrofossil assemblage, but it appears to be strictly local as it is not reflected in the pollen assemblage.

\section{Notes on some of the taxa}

Zygnema tp. Zygospores of Zygnema tp. were rather frequent, occurring throughout the peat deposit. Formation of the spores takes place in stagnant, shallow, more or less mesotrophic freshwater (Van Geel, 1979; Van Geel \& Van der Hammen, 1978).

Alona Guttata. Postabdomens of this species (identified by U. Røen) were found in sample no. 12, 14 and 15 . The species has a very scattered occurrence in West as well as East Greenland, with a northern limit at Danmarkshavn ( $76^{\circ} 45^{\prime} \mathrm{N}$; Røen, 1962).

Calcarius lapponicus (Lapland Bunting). One feather found in sample no. 4 has been ascribed to this species by J. Dyck. It is a common breeding bird along the west coast of Greenland northwards to the Thule district. Along the east coast it breeds northwards to the Angmagssalik district. It occurs as a rare visitor northwards to Inglefield Land and Germania Land. It has not been observed in Peary Land (Salomonsen, 1981).

\section{Palaeoecological reconstruction}

Carex stans is one of the most important plant species of Peary Land. Holmen (1957, p. 109) describes two types of Carex stans meadows, viz. "1. Broad hollows which during the vegetative period are constantly wet. It is here the only species (sometimes single individuals of Eriophorum triste are also found) in a dense cover of mosses, of which Drepanocladus brevifolius is the most conspicuous. 2 . In moist, sandy flats ... Because of the annual accumulation of sand no mosses are found here. Outside Carex stans usually small quantities of Alopecurus alpinus, Melandrium apetalum, Salix arctica and Saxifraga cernua are met with in this vegetation."

Biozone 1 from Vølvedal corresponds to Holmen's second type, and biozone 2 corresponds to his first type. However, in both zones species indicating marshy ground (Zygnema tp., Alona guttata) are found together with species (Cerastium arcticum, Papaver radicatum, Saxifraga oppositifolia and notably Minuartia rubella - represented by seeds) not growing in 


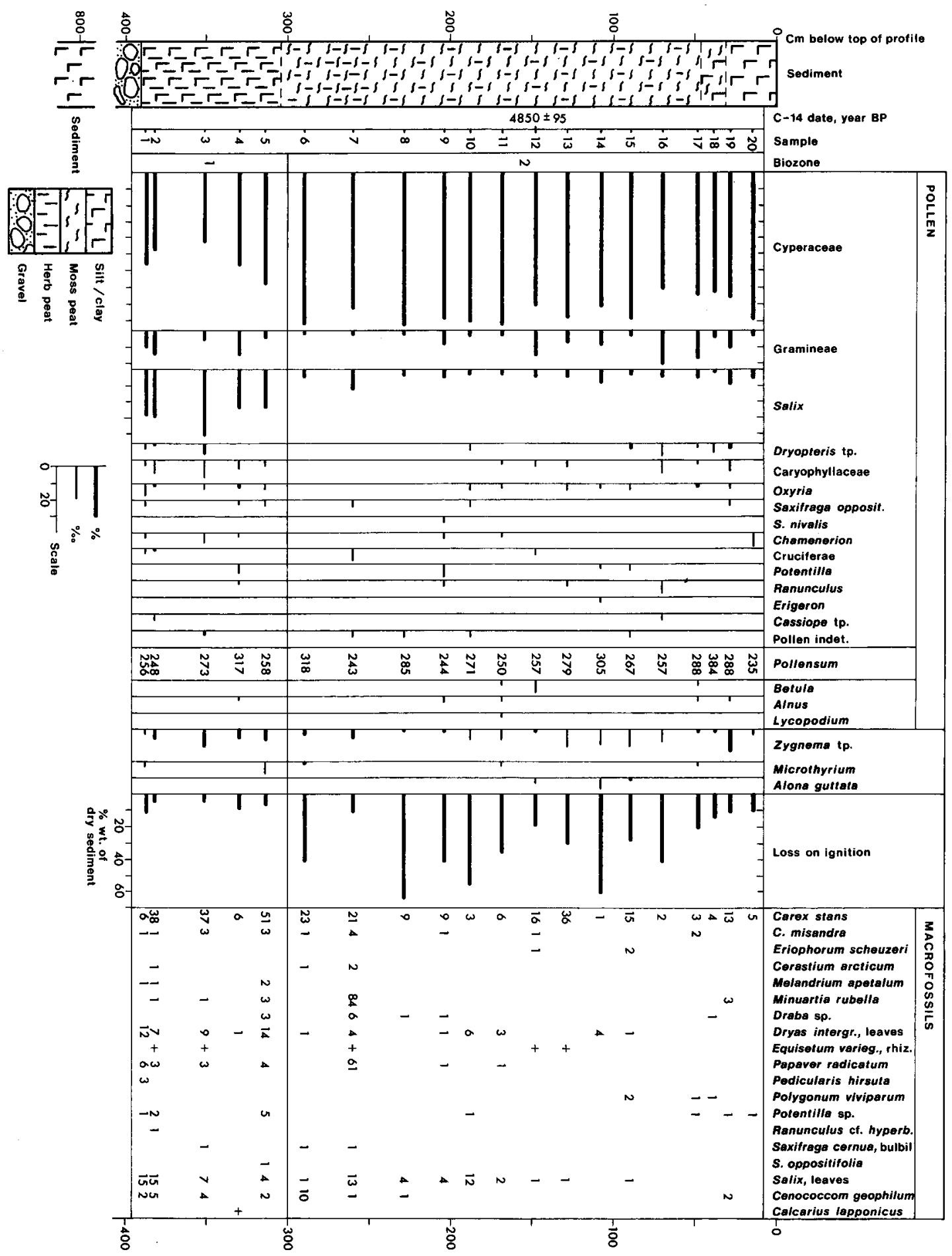


wet soil, giving a rather diverse assemblage. This can be explained by a hummocky ground, with wet and moist soil in close contact. Sample no. 7 might then represent a big hummock.

\section{Discussion and conclusion}

Only two palaeoecological investigations on organic sediments from eastern North Greenland have been published (Fredskild, 1969, 1973). One was carried out on a peat deposit from Sølejren (fig. 4). The fossil assemblage is very similar to the one from Vølvedal, but it dates back to only about 1500 B.P. The other one was carried out on a gyttja sequence from Klaresø (fig. 4). Both localities are situated about $100 \mathrm{~km}$ to the south of Vølvedal.

It was concluded, on the basis of a percentage and an absolute pollen diagram from Klaresø, that the climatic optimum fell within the period 4000 to 3300 B.P. (Fredskild, 1969 , p. 581). However, the dates were unreliable because of pre-Quaternary carbonate in the sediment.

The tripartite division of the peat sediments in Vølvedal can most simply be explained by changes in drainage patterns, while a climatic cause seems less probable. The large amount of peat formed, together with the occurrence of Alona guttata and Calcarius lapponicus, points to higher summer temperatures than at present. Assuming a sedimentation rate of 1 mm per year (very uncertain) these conditions lasted from 7000 B.P. to 4000 B.P.

Acknowledgements. S. Funder's help throughout the study is greatly appreciated. S. Schack Pedersen and C. Marcussen are thanked for good support in the field. B. Fredskild helped with the determination of the macrofossils, U. Røen determined the crustaceans, and J. Dyck determined the feather.

\section{References}

Fredskild, B. 1969: A Postglacial standard pollendiagram from Peary Land, North Greenland (1). Pollen Spores 11, 573-583.

Fredskild, B. 1973: Studies in the vegetational history of Greenland. Palaeobotanical investigations of some Holocene lake and bog deposits. Meddr Grønland 198(4), 247 pp.

Fristup, B. 1952: Winderosion within the Arctic Deserts. Geogr. Tidsskr. 52, 51-65.

Fristrup, B. 1961: Climatological Studies of some High Arctic Stations in North Greenland. Folia Geogr. Danica 9, 67-78.

Funder, S. 1978: Holocene stratigraphy and vegetation history in the Scoresby Sund area, East Greenland. Bull. Grønlands geol. Unders. 129, 66 pp.

Funder, S. 1982: ${ }^{14} \mathrm{C}$-dating of samples collected during the 1979 expedition to North Greenland. Rapp. Grønlands geol. Unders. 110, 9-14.

Holmen, K. 1957: The vascular plants of Peary Land, North Greenland. Meddr Grønland 124(9), 149 pp.

Malaurie, J., Vasari, Y., Hyvärinen, H., Delibras, G. \& Labeyrie, J. 1972: Preliminary remarks on Holocene palaeoclimates in the regions of Thule and Inglefield Land, above all since the beginning of our own era. In Vasari, Y., Hyvärinen, H. \& Hicks, S. (edit.): Climatic changes in arctic areas during the last ten-thousand years. Acta Univ. Oulo. A3, Geol. 1, 105-136.

Meltofte, H. 1976: Ornithological observations in southern Peary Land, North Greenland, 1973. Meddr Grønland 205(1), $57 \mathrm{pp}$.

Fig. 6. Pollen and macrofossils. Vølvedal, North Peary Land, North Greenland. ( $\left.83^{\circ} 02^{\prime} \mathrm{N}, 34^{\circ} 21^{\prime} \mathrm{W}\right)$. GGU no. 217724. Macrofossils from vascular plants are seeds or fruits where nothing else stated. 
Røen, U. 1962: Studies on freshwater Entomostraca in Greenland II. Meddr Grønland 170(2), 249 pp. Salomonsen, F. 1981: Fugle. In Salomonsen, F. (edit.) Grønlands fauna, 161-361. Copenhagen: Gyldendal.

Van Geel, B. 1979: Preliminary report on the history of Zygnemataceae and the use of their spores as ecological markers. Proc. 4. int. Palynol. Conf., Lucknow (1976-77) 1, 467-469.

Van Geel, B. \& Van der Hammen, T. 1978: Zygnemataceae in Quaternary Colombian sediments. Rev. Palaeobot. Palynol. 25, 377-392.

Geologisk Museum,

Oster Voldgade 5-7, DK-1350 Copenhagen $K$.

\title{
Mapping of the Isukasia sheet, southern West Greenland
}

\author{
A. A. Garde, R. P. Hall, D. J. Hughes, S. B. Jensen, A. P. Nutman \\ and $\mathrm{O}$. Stecher
}

Field work for the Isukasia map sheet north of Godthåbsfjord, started in 1981 (Allaart et $a l ., 1982$ ), was continued in 1982. A tent base camp was set up at the fjord Kangiussaq both summers.

In 1982 seventeen field teams and the glaciological station Qamanârssûp sermia were supplied from the base by the GGU cutter J. F. Johnstrup and by a Jet Ranger helicopter based in Kangiussaq. Twelve mapping geologists worked on the two map sheets Ivisârtoq and Isukasia, and five teams carried out ore geological, geochemical and geophysical investigations (see Appel, Chadwick et al., Jensen \& Secher, and Secher, this volume). The field work was carried out from June 20th to August 28th.

The Isukasia map sheet is situated north-east of the head of Fiskefjord, around the lake Taserssuaq. To the east it is bounded by the Inland Ice, from which the glacier Sarqap sermia enters Taserssuaq. Most of the area is a lake strewn, undulating plateau at elevations between 500 and $800 \mathrm{~m}$. Outcrops are generally good although there are some Quaternary boulder fields, the largest of which extends over some $25 \mathrm{~km}^{2}$ in the north-east corner of the map sheet.

The north-north-east trending Ataneq fault zone (see below), which occurs some $25 \mathrm{~km}$ east of Taserssuaq, separates an area of early Archaean rocks (including the Isua supracrustals) from rocks to its west of probable late Archaean age. The younger rocks make up the bulk of the Isukasia map sheet.

\section{Early Archaean rocks east of the Ataneq fault}

In 1982 A.P.N. mapped two areas east of the Ataneq fault: close to the map sheet boundary at $65^{\circ} \mathrm{N}$ and north of the north-eastern splay of the Ataneq fault (fig. 7). It was 